\title{
A Review of the Neutrophil Extracellular Traps (NETs) from Cow, Sheep and Goat Models
}

\author{
Mulumebet Worku ${ }^{1, *(\mathbb{D})}$, Djaafar Rehrah ${ }^{1}$, Hamid D. Ismail ${ }^{1}$, Emmanuel Asiamah ${ }^{2}$ and Sarah Adjei-Fremah ${ }^{3} \mathbb{C}$ \\ 1 Department of Animal Sciences, North Carolina Agricultural and Technical State University, 1601 East Market \\ Street, Greensboro, NC 27411, USA; drehrah@ncat.edu (D.R.); hdismail@ncat.edu (H.D.I.) \\ 2 Department of Agriculture, University of Arkansas at Pine Bluff, 1200 N. University Drive, Mail Slot 4913, \\ Pine Bluff, AR 71601, USA; asiamahe@uapb.edu \\ 3 Research \& Economic Development, North Carolina Agricultural and Technical State University, 1601 East \\ Market Street, Greensboro, NC 27411, USA; sadjeifr@ncat.edu \\ * Correspondence: worku@ncat.edu; Tel.: +1-336-285-4816
}

Citation: Worku, M.; Rehrah, D.;

Ismail, H.D.; Asiamah, E.;

Adjei-Fremah, S. A Review of the

Neutrophil Extracellular Traps (NETs) from Cow, Sheep and Goat Models.

Int. J. Mol. Sci. 2021, 22, 8046.

https: / / doi.org/10.3390/ijms22158046

Academic Editor: Milladur Rahman

Received: 4 May 2021

Accepted: 1 July 2021

Published: 28 July 2021

Publisher's Note: MDPI stays neutral with regard to jurisdictional claims in published maps and institutional affiliations.

Copyright: (c) 2021 by the authors. Licensee MDPI, Basel, Switzerland. This article is an open access article distributed under the terms and conditions of the Creative Commons Attribution (CC BY) license (https:// creativecommons.org/licenses/by/ $4.0 /)$.

\begin{abstract}
This review provides insight into the importance of understanding NETosis in cows, sheep, and goats in light of the importance to their health, welfare and use as animal models. Neutrophils are essential to innate immunity, pathogen infection, and inflammatory diseases. The relevance of NETosis as a conserved innate immune response mechanism and the translational implications for public health are presented. Increased understanding of NETosis in ruminants will contribute to the prediction of pathologies and design of strategic interventions targeting NETs. This will help to control pathogens such as coronaviruses and inflammatory diseases such as mastitis that impact all mammals, including humans. Definition of unique attributes of NETosis in ruminants, in comparison to what has been observed in humans, has significant translational implications for one health and global food security, and thus warrants further study.
\end{abstract}

Keywords: neutrophil extracellular traps NETs; neutrophils; pathogens; humans; ruminants; health; therapy

\section{Introduction}

The welfare and production of ruminant animals such as cows, sheep, and goats are impacted by pathogen induced and metabolic inflammatory diseases. Furthermore, species like cattle, sheep, and goats are useful model animals as they can be both target species for pathogens and reservoirs for human disease [1]. Neutrophils are granular leukocytes that are central to the inflammatory response. They are the most abundant innate immune cells, making up 50-70\% of all leukocytes in humans [2], however, in ruminants such as cattle they comprise less than half of total circulating leukocytes [3,4]. Similarities have been reported in function of ruminant and human neutrophils [5]. Increased understanding of phenotypes and functions of neutrophils of different ruminant species will contribute to animal and public health.

Neutrophils are the first line of defense deploying sophisticated antimicrobial strategies [6] and also contributing to shaping adaptive immune responses [2,7]. The immune regulatory functions of neutrophils against pathogens include phagocytosis, release of antimicrobial molecules, production of reactive oxygen species (ROS), degranulation, and the formation of neutrophil extracellular traps (NETs), a process referred to as NETosis [8]. NETosis is a form of cell death, which is different from apoptosis and necrosis [9,10].

\section{NETosis Mechanisms and Functions}

NETs are large extracellular web-like structures [8] decorated with histones, antimicrobial proteins and DNA allowing them to trap and kill pathogens extracellularly [9,11-14] 
(Figure 1). When neutrophils undergo NETosis, nuclear and granular membranes disintegrate, the chromatin de-condenses, and it diffuses into the cytoplasm, mixing with cytoplasmic proteins [15]. Neutrophil components including neutrophil elastase (NE), myeloperoxidase (MPO), reactive oxygen species (ROS) [16], and peptidyl arginine deiminase 4 (PAD4) which citrullinates histones help to facilitate de-condensation and release of chromosomal DNA [6]. Both NADPH oxidase (NOX)-dependent and independent NETosis have been reported [17]. In addition to their role in host defense NETs are associated with pathologies acting as a double-edged sword in diseases [18-20]. As knowledge about NET's increases, they are recognized as biomarkers of disease [21] for diagnosis and targeted therapy. Establishing efficient and accurate methods for quantifying NETosis under a variety of experimental conditions holds the potential to further elucidate the role of NETs and similar structures in normal and pathological processes [22].

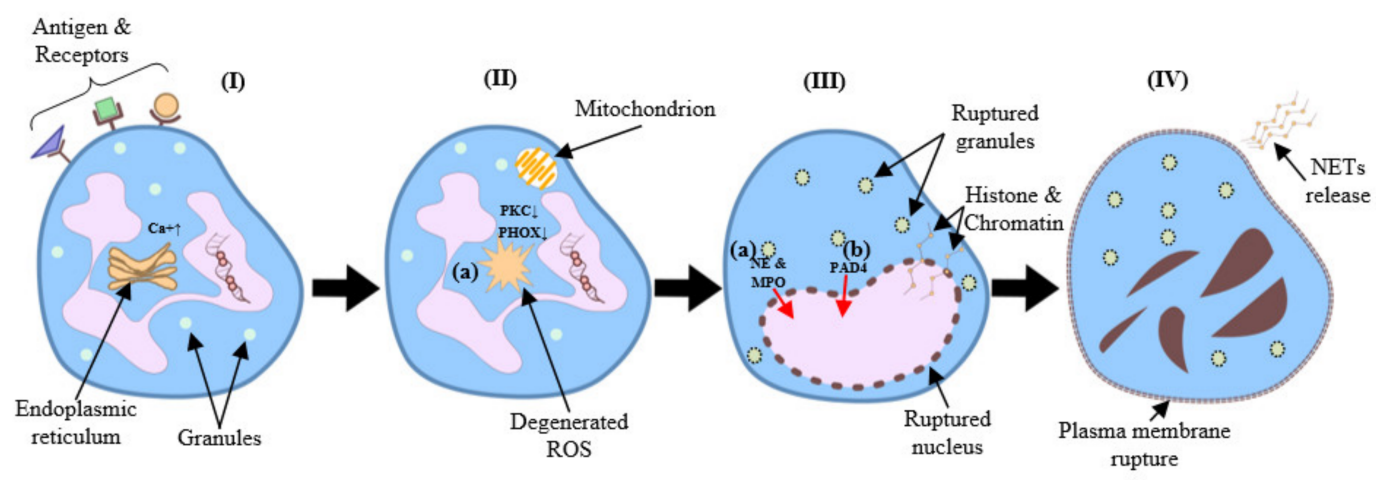

Figure 1. (I) Several stimuli (e.g., bacteria, viruses, fungi) initiate NETosis by binding to neutrophil receptors (e.g., Fc receptors, TLRs), which activate the endoplasmic reticulum to release stored calcium ions. (II) Elevated cytoplasmic calcium levels increase PKC activity, which induces NADPH oxidase to assemble into a functional complex (PHOX). (II-a) Subsequently, PHOX (or alternatively the mitochondrial respiratory chain) generate ROS. (III) ROS generation leads to the rupture of granules and the nuclear envelope. (III-a) Meanwhile, NE and MPO translocate to the nucleus. (III-b) As a result, histone deamination and chromatin de-condensation contribute to the formation of NETs. (IV) Finally, the rupture of the plasma membrane causes neutrophil lysis and allows the release of NETs.

\section{Mammalian Neutrophil Extracellular Traps}

\subsection{Triggers and Phenotpes of Extracellular Traps}

Neutrophils from different mammalian species including humans, horses, dogs, sheep, mice, as well as from invertebrates, form ETs [23-36]. In addition to neutrophils, ETs are formed by other immune cells such as mast cells, monocytes, macrophages, and eosinophils following stimulation with mitogens, cytokines, pathogens, or by interaction with neighboring cells and platelets [37]. Three different pathways result in ET formation: (1) release of nuclear DNA and cell death- suicidal cell pathway [12,38]; (2) release of nuclear DNA by viable cells-nonsuicidal vital NETosis [8,26,39-42]; and (3) release of mitochondrial DNA [43,44]. Genetic, species, and breed differences in mechanisms and efficiency of the NETosis response to pathogens have been reported [23-25] (Table 1).

Table 1. Summary of mechanisms of neutrophil extracellular trap formation in different species.

\begin{tabular}{ccccc}
\hline Microorganisms & Species & Mechanism & Types of NETosis & References \\
\hline & & BACTERIA & & \\
\hline & Mice & Dependent on TLR2 and Complement C3 in mice & & \\
Staphylococcus & PAD4 dependent & Vital & Vital & {$[26]$} \\
aureus & Humans & Response to virulence factor, PVL in a ROS & Unknown & {$[27]$} \\
& Bovine & independent manner & & \\
& & DNA extruded via vesicles & Unknown & \\
\hline
\end{tabular}


Table 1. Cont.

\begin{tabular}{|c|c|c|c|c|}
\hline Microorganisms & Species & Mechanism & Types of NETosis & References \\
\hline E. coli & $\begin{array}{l}\text { Humans * } \\
\text { Mice* } \\
\text { Bovine }\end{array}$ & $\begin{array}{l}\text { * Mediated via platelet TLR4 } \\
\text { Histone H3 citrullination by PAD4 }\end{array}$ & $\begin{array}{l}\text { Vital in the } \\
\text { presence of } \\
\text { platelets }\end{array}$ & $\begin{array}{l}{[39]} \\
{[28]}\end{array}$ \\
\hline E. coli LPS & Humans * & $\begin{array}{l}\text { * Mediated via platelet TLR4 and present HMGB1 } \\
\text { to neutrophils }\end{array}$ & Vital in vivo & [29] \\
\hline \multicolumn{5}{|c|}{ VIRUS } \\
\hline $\begin{array}{l}\text { Influenza A } \\
\text { Influenza H1N1 }\end{array}$ & $\begin{array}{c}\text { Mice } \\
\text { Humans }\end{array}$ & $\begin{array}{l}\text { Not dependent on PAD4 } \\
\text { ROS and PAD4 dependent }\end{array}$ & $\begin{array}{l}\text { Suicidal } \\
\text { Suicidal }\end{array}$ & {$[30]$} \\
\hline \multicolumn{5}{|c|}{ PARASITES } \\
\hline Eimeria bovis & Bovine & $\begin{array}{c}\text { Recognition by CD11b } \\
\text { Dependent on NAPDH oxidase, NE and MPO } \\
\text { Requires p38 MAPK and ERK1/2 phosphorylation }\end{array}$ & Unknown & $\begin{array}{l}{[31]} \\
{[32]}\end{array}$ \\
\hline Eimeria arloingi & Goat & NADPH oxidase dependent & Unknown & [33] \\
\hline Besnoitia besnoiti & Bovine & Dependent on NAPDH oxidase, NE and MPO & Unknown & {$[34]$} \\
\hline $\begin{array}{l}\text { Toxoplasma } \\
\text { gondii }\end{array}$ & $\begin{array}{l}\text { Humans } \\
\text { Mice }\end{array}$ & $\begin{array}{l}\text { ERK-MEK dependent } \\
\text { * NADPH oxidase/ROS dependent }\end{array}$ & Suicidal & [35] \\
\hline
\end{tabular}

TLR, toll-like receptor; C3, complement 3; PAD4, peptidyl arginine deiminase 4; PVL, Panto-Valentine leukocidin; HMGB1, high mobility group box 1; ROS, reactive oxygen species; NE, neutrophil elastase; MPO, myeloperoxidase; MAPK, mitogen-activated protein kinase, ERK1/2; extracellular signal regulated kinase $\frac{1}{2}, \mathrm{NADPH}$; nicotinamide adenine dinucleotide phosphate. ${ }^{*}$ Mechanism found in specified species.

Microbial pathogens that infect man and domestic animals can induce NETosis as part of the host's innate immune response (Table 2) [8]. Diverse pathogen associated molecular patterns (PAMPS) such as the bacterial cell surface components LPS, lipoteichoic acid, and their breakdown products can trigger NETosis [36]. Formation of NETs can immobilize and kill microbes or inactivate microbial "virulence factors" and alter host cell function $[9,16,40]$. Microbes are able to circumvent NETosis using diverse mechanisms such as degrading NETs using nucleases [45]. Encapsulated pathogens or those that can change their surface charge to escape entrapment result in inflammation [46].

Table 2. Microbial inducers of NETosis.

\begin{tabular}{cc}
\hline Inducer Type & Reference \\
\hline Staphylococcus aureus & {$[40,47]$} \\
\hline Streptococcus sp. & {$[48]$} \\
\hline Haemophilus influenzae & {$[49]$} \\
\hline Klebsiella pneumoniae & {$[16]$} \\
\hline Listeria monocytogenes & {$[50]$} \\
\hline Mycobacterium tuberculosis & {$[51]$} \\
\hline Shigella flexneri & {$[9]$} \\
\hline Aspergillus nidulans & {$[52-54]$} \\
\hline Aspergillus fumigatus & \\
\hline Candida albicans & {$[55]$} \\
\hline Porphyromonas gingivalis & {$[45]$} \\
\hline V. cholera & {$[56]$} \\
\hline Aeromonas hydrophila & {$[24,31-34,57-72]$} \\
\hline E. arloingi sporozoites, B. besnoiti, C. parvum, Spermatozoa, H. contortus, N. caninum, D (-) lactic acid, M. bovis, \\
\hline E. ninakohlyakimovae, T. gondii, S. uberis
\end{tabular}


Formation of NETs contributes to the pathogenesis of inflammatory and autoimmune diseases in man. Pathologies associated with NET formation have been reported in systemic lupus erythematosus, rheumatoid arthritis [73], vasculitis [74,75], diabetes [76,77], atherosclerosis and cancer [78]. Excessive NET formation during sepsis [15,79], promotes thrombosis [80], thus enhancing coagulation and may also contribute to organ failure [81,82].

The purpose of this review is to present the current knowledge about the mechanisms of NETosis and its role in the pathogenesis of different diseases affecting three ruminants cows, sheep, and goats [8]. Further the aim is to present and discuss strategies to control parasites and inflammatory diseases by modulating NETosis through dietary or other interventions to promote animal welfare/health, product quality and translational efforts.

\subsection{Extracellular Traps in Ruminants}

Cattle, sheep, and goats are the major food-producing livestock worldwide [83]. Concerns regarding food insecurity are associated with inflammatory diseases and animal production $[84,85]$. The cost of parasitic disease is estimated at tens of billions of dollars worldwide [86]. Drug resistance impacts control of pathogens [87,88]. The innate immune system, primarily leukocytes, serves as the first line of host defense and plays a crucial role in early recognition and the proinflammatory response [89]. Understanding and interpreting neutrophil immune functions in different species [90] is essential to defining early defense mechanisms for better disease management.

Neutrophils are very important first line responders in inflammatory diseases which are associated with pathogen infection and metabolic disorders. They are central to the defense against pathogens causing disease such as mastitis, metritis, and parasitic infections as reviewed by Neumann et al., (2020) [36]. Impairments in neutrophil function such as during the periparturient period are associated with impaired animal health and welfare [91-98]. Furthermore, increased understanding of the regulation of neutrophil function is essential to the control of tissue damage resulting from cell activation and NETosis [99].

NETs have been characterized in several mammals including cows, sheep and goats, although not as extensively as in humans and mice [11]. Proinflammatory components of NET formation are associated with tissue damage in human lung [100] and in cow mammary epithelial cells [101]. It has been observed that direct proinflammatory effects on airway epithelial cells might contribute to recruitment of more neutrophils and perpetuation of inflammation, to cause lung tissue damage [101].

Understanding conserved and different responses of neutrophils from different species is essential to understanding host pathogen interactions to control diseases [90]. Comparative studies on NETosis are helping to advance knowledge about the role of neutrophils in reproduction to improve successful fertilization [102,103]. Understanding NETosis in ruminant species will aid in better definition of pathogenesis of diseases and designing of targeted therapeutics. Moreover, analyzing the responses of neutrophils of different species and NETs formation is relevant in light of zoonotic disease and the use of animal models for health [104-106]. Neutrophils are associated with lesions in the lungs and gastrointestinal tract of cows, sheep, and goats infected by coronaviruses and diverse pathogens [107]. Understanding NETosis in these species may help understand the pathophysiology and adaptability of animal and zoonotic pathogens while contributing to animal and public health through new targets for control [107].

\section{NET Triggers in Cattle, Sheep and Goats}

Cattle, sheep and goats are susceptible to inflammatory diseases caused by pathogens and as a result of metabolic disorders. These diseases are important limiting factors in production systems around the world resulting in economic losses [108]. The mechanism of activation, migration into tissue and immune modulation in response to stimuli, microbial killing and NETosis of cow, sheep and goat neutrophils is similar to other species [109]. 
In cows, stimulation of neutrophils with bacteria common to mammary gland infections leads to neutrophil extracellular traps formation in milk [27]. Studies in sheep have shown that NETosis is associated with changes in proteins such as TLR in response to pathogens that cause mastitis [72]. Pisanu et al., (2015) described NET formation in vivo where milk and tissues collected from the mammary gland of sheep that developed acute mastitis after experimental Streptococcus uberis infection, demonstrated the presence of extra nuclear DNA co-localizing with antimicrobial proteins, histones, and bacteria [72]. Histone citrullination formation plays a role in NETs found in mammary alveoli in response to $S$. uberis infection [72]. Studies on bovine mammary epithelial cells have implicated NET formation and in particular histones to be involved in mammary epithelial cell damage in vitro [101]. Targeted inhibition of excess NET formation may aid in combatting tissue damage [101,110]. In this study NET markers were markedly increased, 1095 unique proteins were identified, with 287 being significantly more abundant in mastitic milk [72]. These markers may aid in targeted inhibition of excess NET formation [72,110].

Cacciotto et al., (2016) described NET formation in vivo in the mammary gland and milk of sheep naturally infected by Mycoplasma agalactiae [111]. Sheep neutrophils formed NETs through binding of the lipoprotein to TLR2. Furthermore, the authors suggested that M. agalactiae may circumvent NETosis by degrading the DNA component of NETs through its surface nuclease MAG_5040. Thus promoting its survival and the establishment of persistent infections [111]. Understanding of microbial virulence factors may aid in design of novel diagnostics and therapeutics for the control of pathogens such as mycoplasma. Pathogens such as Mycoplasma bovis, can escape NET-mediated killing [57,58]. Relative senescence of individual cow neutrophils was associated with increased NET formation in response to repeated exposure to $M$. haemolytica [112]. Viable and heat-killed M. tuberculosis bacteria and unilamellar liposomes, as well as Mycobacterium bovis BCG were efficient NET inducers [51]. Although bacteria remained viable it was postulated that in vivo, neutrophils might propitiate recruitment and activation of more efficient microbicidal cells [51]. In addition to their direct interactions with invading pathogens, NETs can exert a direct enhancement or dampening effect on the inflammatory responses [11].

Neutrophils release ETs as a defense strategy against pathogens $[24,27,28,31,32,65$, 67,68,70,113-115]. These parasites include Eimeria bovis [31,32,67], Neospora caninum [59], trypomastigotes [116] and Haemonchus contortus [64]. Pathogens can be entrapped and killed within NET-like structures in a ROS-dependent or independent manner $[32,59,63]$. The extracellular, haemoflagellate parasite Trypanosoma brucei is a cause of trypanosomiasis resulting in mortality and morbidity in cattle, sheep, goats, and horses. The entrapment of trypmastigotes in aggregated NETs was purinergic-dependent and maybe important in trypanosomiasis-related immune-pathological disorders [116]. Neospora caninum is an apicomplexan intracellular parasite of cattle and dogs that also cause clinical infections in horses, goats, sheep, and deer. It causes severe reproductive disorders in cattle worldwide. Neospora caninum, induced classical mammalian NET formation in cow and goat neutrophils $[117,118]$. N.caninum-induced NETosis appears to be influenced by MPO and CD11b, but independent of NADPH oxidase, store-operated calcium entry, ERK1/2 and p38 MAPK activities $[117,118]$. Toxoplasma gondii, a protozoan parasite that causes toxoplasmosis in warm-blooded animals triggers NETs in human, mouse, sheep and cattle neutrophils [68]. T. gondii-induced NETosis was dependent on tachyzoite concentrations and incubation time in both sheep and cattle. NETs structures released from sheep neutrophils caused mechanical immobilization of $T$. gondii tachyzoites. NETs structures and MPO may have a lethal effect on T. gondii tachyzoites in vitro [36,68]. Yildiz et al., (2017) reported that NET structures produced by sheep neutrophils may only ensnare $T$. gondii tachyzoites, whereas cattle neutrophils had lethal effects in vitro [68].

Cattle sheep and goats are infected with different species of the genus Eimeria a protozoan parasite causing coccidiosis. Eimeria bovis in cattle or Eimeria arloingi in goats are associated with health problems and economic losses especially in young animals [63-65]. Eimeria arloingi triggered the release of ROS-dependent caprine neu- 
trophil ET fibers and were entrapped within the meshwork [33]. Although E. arloingi were immobilized within the NETs, this did not affect the viability of the parasites [33]. Findings from several studies reported that triggering of NETs is dependent on incubation time in bovine and caprine neutrophils against parasites such as E. bovis, C. parvum and E. arloingi sporozoites $[32,33,65]$ contradicting what was reported with tachyzoites of B. besnoiti [34]. The induction of caprine NETs by E. arloingi was confirmed by Munoz-Caro et al., (2016), who reported colocalization of extracellular DNA with neutrophil elastase and histones in Eimeria-infected tissue samples [66]. Citrullinated histone H3, a typical NET marker for human and mouse NETs [119], was found in close proximity to Eimeria in different stages of replication. NADPH-oxidase-dependent NETosis was described in response to viable sporozoites, sporocysts, and oocysts of Eimeria ninakohlyakimovae, in association with increased IL-12 and TNF $\alpha$ in goats [61,62]. The authors hypothesized that the released DNA structures immobilized rather than killed the parasites. Moreover, caprine monocytes also released ETs [61,62].

Many species of parasitic helminths are impacted by NETosis as part of the early immune response of the host. The abomasal parasite Haemonchus contortus is a gastrointestinal nematode with worldwide distribution causing significant economic losses particularly in small ruminants. In cow and sheep neutrophils L3 larvae of Haemonchus contortus [64] induce different phenotypes such as aggregated NETs, spread NETs and diffuse NETs. Both disseminated and aggregated NETs entrapped L3 [64]. The viability of H. contortus was not affected by entrapment [68]. Studies have demonstrated that cow neutrophils release NETs in response to the free-living soil nematode Caenorhabditis elegans, that NET production may be a conserved mechanism against a broad range of nematodes. The cattle stomach worm $O$. ostertagi-induced NET formation by a ROS-independent and NADPH oxidase dependent pathway [120]. Fascioliasis is a zoonotic disease caused by infection with the trematode Fasciola hepatica, resulting in hepatitis in humans and livestock. Pathogens employ virulence factors and molecular mimicry to avoid detection or trigger immune modulatory factors to impact the NETotic response [121]. Fasciola hepatica secretes parasite-specific molecules to either resolve NETs or to impair NETosis signaling pathways to possibly impact disease pathology in vivo [122].Thus more studies are needed on pathogen recognition to shed light on mechanisms of immune evasion related to NETosis.

Exposure to molecular stimuli other than pathogens is also associated with the NET formation. For example, PMA, ionomycin or milk each induced NETosis in contrast to inhibition of phagocytosis and oxidative burst observed in cow blood [27]. The release of NETs, inhibition by milk components, and association of relevant proteins with the milk fat has been reported [27]. Beta-hydroxybutyrate, produced during ketosis or hyperketonemia, reduced phagocytosis and NET-mediated killing of E. coli P4 by neutrophils [28]. Alarcon et al., (2020) reported that nonesterified fatty acids (NEFAs), by inducing NET formation may contribute to postpartum diseases in cows. The effect of NEFA in cow neutrophils was faster than reports for human neutrophils [123]. Alacron et al., 2017 [60]. Reported that activation of NETosis with d (-) lactic may contribute to neutrophil-derived proinflammatory processes, such as aseptic laminitis and/or polysynovitis in animals suffering from acute ruminal acidosis [60]. Histamine regulates the immune response in allergic diseases such as asthma, rhinitis in man and laminitis in cows through regulating immune responses. Histamine-triggered NETosis increased ERK and p38s proteins and activation of NADPH oxidase in cows [124]. Thus changes in the host microenvironment that impact NETosis can impact disease outcome.

\section{Prediction, Modulation and Therapy}

The innate immune response involves evolutionarily conserved pathogen recognition receptors (PRR) that recognize PAMPS. This is exemplified by toll-like receptors (TLR), which recognize specific PAMPS such as LPS [125]. In light of reports of the role of TLR in NETosis, understanding the mechanisms underlying regulation of the inflammatory response to PAMPs in diseases such as mastitis and metritis may aid in the design of tailored 
therapeutics that target pathogen recognition and inflammation [126]. For effective use of NETs as biomarkers and targets for therapy, continued efforts are needed to identify and define the function of genes involved in innate immunity. Furthermore, we need to develop tools that identify and predict NETosis phenotypes in cattle, sheep and goats. Anti-NET therapeutics that target induction or inhibition of NET formation are being studied in human neutrophils [106]. The machine learning algorithm called convolutional neural network was used to quantitate and identify NETotic and non-NETotic classes with an accuracy of greater than 94\% [127]. The design of new and implementation of improved machine learning tools may help capture unique attributes/features of NETosis in ruminants in comparison to what has been observed in human for increased understanding [127].

Development of novel anti-NET therapeutic strategies might help to reduce disease and improve animal welfare and production. Dietary modulation that targets NETosis may enhance the functional benefits while regulating harmful consequences [123]. Diverse stimuli are associated with differential and temporal modulation of gene expression in ruminant blood and in immune cells such as neutrophils [92,99,106].

Phytochemicals and probiotics $[99,105,128,129]$ are being studied to augment innate immunity against microbes and gastrointestinal parasites to address concerns regarding antibiotic resistance. These include extracts such as: garlic, neem, wormwood, tobacco, cowpea $[87,130,131]$ and Sericea lespedeza [132]. [Table 3]. As reported by Vong et al., (2014) probiotic bacteria inhibit both PMA- and S. aureus-induced NETosis [110]. Furthermore, this inhibition of NETosis is an additional benefit of PAMPS expressed by health beneficial microorganism playing a role in maintaining homeostasis and gastrointestinal health $[95,108]$. Genes associated with innate and adaptive immunity are differentially regulated in cows and goats receiving probiotics $[95,108]$. Adjei-Fremah et al., (2016) investigated the in vitro effect of LPS using blood samples collected from probiotics-treated animals. Global gene expression analysis identified 13,658 differentially expressed genes (fold change cutoff $\geq 2, p<0.05$ ), 3816 upregulated genes and 9842 downregulated genes in blood in response to LPS $[133,134]$. The regulation of the genes involved in inflammation signaling pathway suggests that probiotics may stimulate the innate immune response of animal against parasitic and bacterial infections [95] The effect of probiotics on NETosis in ruminants needs investigation.

Antioxidants can inhibit ROS-associated NET release $[135,136]$. Studies are needed to evaluate the effect of antioxidants as modulators of NETosis in cows, sheep and goats $[110,131,133,134]$. Polyphenolic extracts from cowpea (Vigna unguiculata) [98] have been shown to change gene expression [137] and activate signaling pathways such as the toll-like receptor pathway, inflammation response pathway and MAPK cascade pathways, among others $[130,138]$. Animal feed rich in phenolic constituents has immuno-regulatory effects in ruminants $[139,140]$. Forages rich in polyphenol such as Sericea lespedeza and cowpea also changed gene expression in goat blood [128,130,132,141]. Asiamah et al., [92] showed extracts from Sericea lespedeza modulated the expression of innate and adaptive immune and WNT signaling pathway genes including TLR2, TLR4, WNT5A and FZD. Table 3 shows genes, modulated as a result of probiotic and phytochemicals supplementation in goats [108,142], that may impact NETosis.

Table 3. Selected immunomodulators tested in goat blood.

\begin{tabular}{|c|c|c|c|c|}
\hline Modulator (s) & Sample Type (s) & Cytokines & $\begin{array}{l}\text { Innate Immune } \\
\text { Response }\end{array}$ & Reference \\
\hline Probiotics & Whole blood, serum & IL2, IL5, IL10, IL8, IL18 & $\begin{array}{l}\text { TLR4, TLR6, } \\
\text { TLR7, TLR9 }\end{array}$ & {$[96,143]$} \\
\hline Cowpea & Whole blood, serum, plasma & $\begin{array}{c}\text { TNF } \alpha, \text { IL1 } \alpha, \text { IL } \beta, \text { IL8 IL10RA, } \\
\text { IL15, IP10, } \\
\text { GCSF, Rantes and IFN } \gamma\end{array}$ & TLR2 & [139] \\
\hline Sericea lespedeza & Whole blood, Serum & $\begin{array}{c}\text { TNF- } \alpha, \text { IFNr, GCSF, GMCSF, } \\
\text { IL- } 1 \alpha, \text { IP-10 }\end{array}$ & TLR2 and TLR4 & [132] \\
\hline
\end{tabular}


Table 3. Cont.

\begin{tabular}{|c|c|c|c|c|}
\hline Modulator (s) & Sample Type (s) & Cytokines & $\begin{array}{l}\text { Innate Immune } \\
\text { Response }\end{array}$ & Reference \\
\hline Mushroom & $\begin{array}{l}\text { Neutrophils, Whole blood, } \\
\text { serum }\end{array}$ & $\begin{array}{c}\text { IFNr, Rantes, GCSF, and } \\
\text { GM-CSF }\end{array}$ & $\begin{array}{l}\text { TLR1, TLR2, } \\
\text { TLR3, TLR4, } \\
\text { TLR5, TLR6, } \\
\text { TLR7, TLR8, } \\
\text { TLR9, TLR10 }\end{array}$ & [142] \\
\hline Lipopolysaccharide & $\begin{array}{c}\text { Mammary epithelial cells, } \\
\text { whole blood, blood } \\
\text { leukocytes }\end{array}$ & $\begin{array}{l}\text { IL1B, CCL3 and IL8, CCL2, } \\
\text { CXCL6, IL6, CXCL8 }\end{array}$ & $\begin{array}{c}\text { PTGS2, IFIT3, } \\
\text { MYD88, NFKB1, and } \\
\text { TLR4 }\end{array}$ & {$[92,144]$} \\
\hline
\end{tabular}

IL2, interleukin 2; TLR, Toll-like receptor; TNF $\alpha$, tumor necrosis factor $\alpha$; GCSF, granulocyte colony stimulating factor; IFN $\gamma$, interferon $\gamma$; GMCSF, granulocyte macrophage colony stimulating factor; IP-10, IFN- $\gamma$-induced protein 10; IFNr, interferon regulator; CCL3, macrophage inflammatory protein-1 $\alpha$, MIP-1 $\alpha$; CXCL6, chemokine (C-X-C motif) ligand 6.

Dietary modulation to improve immuno-suppression during the periparturient period can impact NETosis and immune function [123] Global gene expression profiles of bloodderived neutrophils from periparturient cows revealed that 249 genes out of 44,000 were differentially expressed (fold change $\geq 2, p<0.05$ ). Eighty-seven (87) genes were downregulated and among the top 20 downregulated genes were genes essential to neutrophil response and immunity [145], such as PGLYRP1 and SERPINB4. The observed downregulation of adhesion genes could lead to impaired NETosis during the periparturient period. Erpenbeck et al., (2019) reported a correlation between neutrophil adhesion/contact area and NETosis [99]. They demonstrated that, PMA induced NETosis is independent of adhesion and LPS-induced NETosis was dependent on adhesion to specific surfaces in the body [99].

Changes in neutrophil gene expression and function due to supplementation of the cow's diet with rumen-protected methionine (Met) aid in alleviating immune suppression during the periparturient period [146-149]. A study by Stella et al., (2018) revealed that NET formation does not appear to be affected by limited amino acids during the periparturient period [150]. In vitro, addition of Met, as a scavenger of hypochlorous acid, a product of MPO, had no effect following stimulation with PMA or bacteria [151]. Methionine sulfoxidation is a post-translational modification observed in PMA- and LPS-induced NETs [152]. In cows Asiamah et al., (2019) reported an association between dietary Met supplementation and galectin gene expression and secretion [153].

Galectins are soluble $\beta$-galactoside-binding lectins that regulate immune function [154]. Galectin-9 is reported to co-localize with corpses of neutrophils following NETosis, suggesting a potential role in the clearance of neutrophils [155]. Supplementation of dairy cows with Met reduced the galectins involved in inflammation (galectins 1, 2, 3, 4 and 12) [143]. The increase of galectin 8 to Met supplementation in the presence of LPS in vitro, however, shows a possible pro-inflammatory role of this galectin in cows [156]. Furthermore, Met supplementation may improve neutrophil migration and phagocytic capacity in part by increasing the expression of galectin 8 in cow neutrophils [91,93]. Galectin 8 is involved in activating anti-bacterial autophagy [157]. Nishi et al., (2003) reported that galectin 8 induces a firm and reversible adhesion of peripheral blood neutrophils in vitro [156], which suggests that they play a vital role in neutrophil migration. It is possible that cows with more Met may respond better to infection through enhancement of adhesion in response to LPS and formation of NETs [153].

Breed and species-specific patterns of NETosis offer an opportunity to harness genomic technologies for targeted intervention and immunomodulation of conserved receptor signaling pathways using ruminants as models $[125,158]$. Studies are showing that NETs induced in different conditions may have different biological effects [152]. Using proteome analysis, it was shown that NETs induced by different stimuli had heterogeneous protein composition and post-translational modifications [152]. Changing the proteome by degrading NETs using deoxyribonuclease to reduce inflammation is a therapeutic approach with 
implications in both human and animal diseases [151]. In cattle sheep and goats, changes in NET markers and the proteome are associated with disease of concern to animal health and production [72]. Increased definition of the proteomes, associated post-translational modifications, and markers of NETosis in sheep cattle and goats will contribute to the development of therapeutics for inhibition of excess NETs formation to ameliorate pathologies associated with diseases [101,129,152,158].

\section{Conclusions}

In cattle, sheep, and goats NETosis is associated with the response to diverse zoonotic pathogens and those impacting animal health and welfare. Pathophysiological damage has been reported from NETosis in humans and ruminants. Increased understanding of NETosis in ruminants will help in interventions to control diseases such as mastitis that impact all mammals, including humans. Species specific responses to pathogens such as coronaviruses in relation to NET formation in ruminants, may contribute to definition of the role of neutrophils in pathophysiology and severity of diseases such as COVID-19. Studies on the innate immune response to pathogens and their modulation using natural products can serve as a springboard for definition of NETosis signatures and their modulation in ruminants. Furthermore, NETosis is associated with impaired fertilization, periparturient health, and diet. Improvements in methodology such as application of machine learning tools are essential to decipher and harness the components of the double edge sword of NET formation as biomarkers for disease and as targets for therapeutic intervention. Studies on the innate immune response to pathogens and their modulation using natural products can serve as a springboard for application of anti-NETosis therapeutics for cows, sheep and goats. Breed and species-specific patterns of NETosis offer an opportunity to harness genomic technologies for targeted intervention and immunomodulation of conserved receptor signaling pathways using ruminants as models. Definition of the NET proteome and its unique attributes/features in ruminants in comparison to what has been observed in humans has significant implications for the design of therapeutics for health and global food security, and thus warrants further study.

Author Contributions: All authors contributed to the writing of this review paper. All authors have read and agreed to the published version of the manuscript.

Funding: This work is supported by the USDA National Institute of Food and Agriculture, [EvansAllen] project [NX.X320-5-19-120-1] Molecular signatures and regulatory checkpoints for animal health.

Conflicts of Interest: The authors declare no conflict of interest.

\section{Abbreviations}

$\begin{array}{ll}\text { IFN } & \text { interferon } \\ \text { IP-10 } & \text { IFN- } \gamma \text {-induced protein } 10 \\ \text { IFN- } \alpha & \text { interferon } \alpha \\ \text { IL } & \text { interleukin } \\ \text { MPO } & \text { myeloperoxidase } \\ \text { NE } & \text { neutrophil elastase } \\ \text { ETs } & \text { extracellular traps } \\ \text { NETs } & \text { neutrophil extracellular traps } \\ \text { Nox } & \text { NADPH-oxidase } \\ \text { PMA } & \text { phorbol-12-myristate-13-acetate } \\ \text { ROS } & \text { reactive oxygen species } \\ \text { SARS-CoV-2 } & \text { severe acute respiratory syndrome coronavirus } 2 \\ \text { SLE } & \text { systemic lupus erythematosus } \\ \text { TNF- } \alpha & \text { tumor necrosis factor- } \alpha \\ \text { BPI } & \text { bactericidal permeability-increasing factor } \\ \text { ERK1/2 } & \text { extracellular signal-regulated kinases } 1 / 2\end{array}$




\begin{tabular}{|c|c|}
\hline LPS & lipopolysaccharide \\
\hline TLR & Toll-like receptor \\
\hline $\mathrm{C} 3$ & complement 3 \\
\hline PAD4 & peptidyl arginine deiminase 4 \\
\hline PVL & Panto-Valentine leukocidin \\
\hline HMGB1 & high-mobility group box 1 \\
\hline MAPK & mitogen-activated protein kinase hi \\
\hline NADPH & nicotinamide adenine dinucleotide phosphate \\
\hline PAMPs & pathogen-associated molecular patterns \\
\hline $\mathrm{CD} 11 \mathrm{~b}$ & cluster of differentiation molecule $11 \mathrm{~b}$ \\
\hline CD14 & cluster of differentiation antigen 14 \\
\hline PMNs & polymorphonuclear leukocytes \\
\hline $\mathrm{CH} 3$ & citrullinated Histone $\mathrm{H} 3$ \\
\hline NEFAs & nonesterified fatty acids \\
\hline ICAM-1 & intercellular Adhesion Molecule 1 \\
\hline PVD & purulent vaginal discharge \\
\hline MAC-1 & macrophage- 1 antigen \\
\hline FC & fold change \\
\hline NFkB & nuclear factor kappa-light-chain-enhancer of activated B cells \\
\hline IL1B & interleukin 1 beta or lymphocyte activating factor (cytokine protein) \\
\hline FZD & frizzled \\
\hline PGLYRP1 & gene peptidoglycan recognition protein 1 gene \\
\hline SERPINB4 & protein serpin family B member 4 protein \\
\hline PMNL & polymorphonuclear leukocytes \\
\hline Met & methionine \\
\hline RPM & rumen-protected Met \\
\hline GCSF & granulocyte colony stimulating factor \\
\hline GMCSF & granulocyte macrophage colony stimulating factor \\
\hline $\mathrm{CoV}$ & coronavirus \\
\hline $\mathrm{BCoV}$ & bovine $\mathrm{CoV}$ \\
\hline PRRs & pattern recognition receptors \\
\hline $\mathrm{CNN}$ & convolutional neural network \\
\hline NEFAs & nonesterified fatty acids \\
\hline CCL3 & macrophage inflammatory protein $-1 \alpha$, MIP- $1 \alpha$ \\
\hline CXCL6 & chemokine (C-X-C motif) ligand 6 \\
\hline SOCE & store-operated calcium entry \\
\hline
\end{tabular}

\section{References}

1. Bailey, M.; Christoforidou, Z.; Lewis, M.C. The evolutionary basis for differences between the immune systems of man, mouse, pig and ruminants. Vet. Immunol. Immunopathol. 2013, 152, 13-19. [CrossRef]

2. Döhrmann, S.; Cole, J.N.; Nizet, V. Conquering Neutrophils. PLoS Pathog. 2016, 12, e1005682. [CrossRef] [PubMed]

3. George, J.W.; Snipes, J.; Lane, V.M. Comparison of bovine hematology reference intervals from 1957 to 2006 . Vet. Clin. Pathol. 2010, 39, 138-148. [CrossRef] [PubMed]

4. Bassel, L.L.; Caswell, J.L. Bovine neutrophils in health and disease. Cell Tissue Res. 2018, 371, 617-637. [CrossRef]

5. Tian, S.Z.; Chang, C.J.; Chiang, C.C.; Peh, H.C.; Huang, M.C.; Lee, J.-W.; Zhao, X. Comparison of morphology, viability, and function between blood and milk neutrophils from peak lactating goats. Can. J. Vet. Res. 2005, 69, 39-45. [PubMed]

6. Janiuk, K.; Jabłońska, E.; Garley, M. Significance of NETs Formation in COVID-19. Cells 2021, 10, 151. [CrossRef]

7. Mócsai, A. Diverse novel functions of neutrophils in immunity, inflammation, and beyond. J. Exp. Med. 2013, 210, 1283-1299. [CrossRef]

8. Yang, H.; Biermann, M.H.; Brauner, J.; Liu, Y.; Zhao, Y.; Herrmann, M. New Insights into Neutrophil Extracellular Traps: Mechanisms of Formation and Role in Inflammation. Front. Immunol. 2016, 7, 302. [CrossRef] [PubMed]

9. Brinkmann, V.; Reichard, U.; Goosmann, C.; Fauler, B.; Uhlemann, Y.; Weiss, D.S.; Weinrauch, Y.; Zychlinsky, A. Neutrophil extracellular traps kill bacteria. Science 2004, 303, 1532-1535. [CrossRef]

10. Steinberg, B.E.; Grinstein, S. Unconventional Roles of the NADPH Oxidase: Signaling, Ion Homeostasis, and Cell Death. Sci. STKE 2007, 2007, pe11. [CrossRef]

11. Mendez, J.; Sun, D.; Tuo, W.; Xiao, Z. Bovine neutrophils form extracellular traps in response to the gastrointestinal parasite Ostertagia ostertagi. Sci. Rep. 2018, 8, 17598. [CrossRef]

12. Fuchs, T.A.; Abed, U.; Goosmann, C.; Hurwitz, R.; Schulze, I.; Wahn, V.; Weinrauch, Y.; Brinkmann, V.; Zychlinsky, A. Novel cell death program leads to neutrophil extracellular traps. J. Cell Biol. 2007, 176, 231-241. [CrossRef] [PubMed] 
13. Hermosilla, C.; Caro, T.M.; Silva, L.M.R.; Ruiz, A.; Taubert, A. The intriguing host innate immune response: Novel anti-parasitic defence by neutrophil extracellular traps. Parasitology 2014, 141, 1489-1498. [CrossRef]

14. De Buhr, N.; von Köckritz-Blickwede, M. How Neutrophil Extracellular Traps Become Visible. J. Immunol. Res. 2016, 2016, 4604713. [CrossRef] [PubMed]

15. Li, R.H.L.; Tablin, F. A Comparative Review of Neutrophil Extracellular Traps in Sepsis. Front. Vet. Sci. 2018, 5, 291. [CrossRef]

16. Papayannopoulos, V.; Metzler, K.D.; Hakkim, A.; Zychlinsky, A. Neutrophil elastase and myeloperoxidase regulate the formation of neutrophil extracellular traps. J. Cell Biol. 2010, 191, 677-691. [CrossRef]

17. Douda, D.N.; Khan, M.A.; Grasemann, H.; Palaniyar, N. SK3 channel and mitochondrial ROS mediate NADPH oxidaseindependent NETosis induced by calcium influx. Proc. Natl. Acad. Sci. USA 2015, 112, 2817-2822. [CrossRef] [PubMed]

18. Euler, M.; Hoffmann, M.H. The double-edged role of neutrophil extracellular traps in inflammation. Biochem. Soc. Trans. 2019, 47, 1921-1930. [CrossRef]

19. Lapponi, M.J.; Carestia, A.; Landoni, V.I.; Rivadeneyra, L.; Etulain, J.; Negrotto, S.; Pozner, R.G.; Schattner, M. Regulation of Neutrophil Extracellular Trap Formation by Anti-Inflammatory Drugs. J. Pharmacol. Exp. Ther. 2013, 345, 430-437. [CrossRef]

20. Kaplan, M.J.; Radic, M. Neutrophil Extracellular Traps: Double-Edged Swords of Innate Immunity. J. Immunol. 2012, 189, 2689-2695. [CrossRef] [PubMed]

21. Gupta, S.; Kaplan, M. The role of neutrophils and NETosis in autoimmune and renal diseases. Nat. Rev. Nephrol. 2016, 12, 402-413. [CrossRef] [PubMed]

22. Rebernick, R.; Fahmy, L.; Glover, C.; Bawadekar, M.; Shim, D.; Holmes, C.L.; Rademacher, N.; Potluri, H.; Bartels, C.M.; Shelef, M.A. DNA Area and NETosis Analysis (DANA): A High-Throughput Method to Quantify Neutrophil Extracellular Traps in Fluorescent Microscope Images. Biol. Proced. Online 2018, 20, 7. [CrossRef] [PubMed]

23. Garza, J.J.; Greiner, S.P.; Bowdridge, S.A. Ovine vital neutrophil extracellular traps bind and impair Haemonchus contortus L3 in a breed-dependent manner. Parasite Immunol. 2018, 40, e12572. [CrossRef] [PubMed]

24. Swain, D.K.; Kushwah, M.S.; Kaur, M.; Patbandha, T.K.; Mohanty, A.K.; Dang, A. Formation of NET, phagocytic activity, surface architecture, apoptosis and expression of toll like receptors 2 and 4 (TLR2 and TLR4) in neutrophils of mastitic cows. Vet. Res. Commun. 2014, 38, 209-219. [CrossRef]

25. Thiam, H.R.; Wong, S.L.; Wagner, D.D.; Waterman, C.M. Cellular Mechanisms of NETosis. Annu. Rev. Cell Dev. Biol. 2020, 36, 191-218. [CrossRef]

26. Yipp, B.; Petri, B.; Salina, D.; Jenne, C.N.; Scott, B.N.V.; Zbytnuik, L.D.; Pittman, K.; Asaduzzaman, M.; Wu, K.; Meijndert, H.C.; et al. Infection-induced NETosis is a dynamic process involving neutrophil multitasking in vivo. Nat. Med. 2012, 18, 1386-1393. [CrossRef] [PubMed]

27. Lippolis, J.D.; Reinhardt, T.; Goff, J.P.; Horst, R.L. Neutrophil extracellular trap formation by bovine neutrophils is not inhibited by milk. Vet. Immunol. Immunopathol. 2006, 113, 248-255. [CrossRef]

28. Grinberg, N.; Elazar, S.; Rosenshine, I.; Shpigel, N.Y. Beta-hydroxybutyrate abrogates formation of bovine neutrophil extracellular traps and bactericidal activity against mammary pathogenic Escherichia coli. Infect. Immun. 2008, 76, 2802-2807. [CrossRef]

29. Pieterse, E.; Rother, N.; Yanginlar, C.; Hilbrands, L.B.; Van Der Vlag, J. Neutrophils Discriminate between Lipopolysaccharides of Different Bacterial Sources and Selectively Release Neutrophil Extracellular Traps. Front. Immunol. 2016, 7. [CrossRef]

30. Hemmers, S.; Teijaro, J.R.; Arandjelovic, S.; Mowen, K.A. PAD4-Mediated Neutrophil Extracellular Trap Formation Is Not Required for Immunity against Influenza Infection. PLoS ONE 2011, 6, e22043. [CrossRef] [PubMed]

31. Muñoz-Caro, T.; Mena Huertas, S.J.; Conejeros, I.; Alarcon, P.; Hidalgo, M.A.; Burgos, R.A.; Hermosilla, C.; Taubert, A. Eimeria bovis-triggered neutrophil extracellular trap formation is CD11b-, ERK 1/2-, p38 MAP kinase- and SOCE-dependent. Vet. Res. 2015, 46, 23. [CrossRef] [PubMed]

32. Behrendt, J.H.; Ruiz, A.; Zahner, H.; Taubert, A.; Hermosilla, C. Neutrophil extracellular trap formation as innate immune reactions against the apicomplexan parasite Eimeria bovis. Vet. Immunol. Immunopathol. 2010, 133, 1-8. [CrossRef]

33. Silva, L.M.R.; Caro, T.M.; Gerstberger, R.; Vila-Viçosa, M.J.M.; Cortes, H.; Hermosilla, C.; Taubert, A. The apicomplexan parasite Eimeria arloingi induces caprine neutrophil extracellular traps. Parasitol. Res. 2014, 113, 2797-2807. [CrossRef]

34. Muñoz-Caro, T.; Silva, L.M.R.; Ritter, C.; Taubert, A.; Hermosilla, C. Besnoitia besnoiti tachyzoites induce monocyte extracellular trap formation. Parasitol. Res. 2014, 113, 4189-4197. [CrossRef]

35. Abdallah, D.S.A.; Lin, C.; Ball, C.J.; King, M.R.; Duhamel, G.E.; Denkers, E.Y. Toxoplasma gondii Triggers Release of Human and Mouse Neutrophil Extracellular Traps. Infect. Immun. 2011, 80, 768-777. [CrossRef]

36. Neumann, A.; Brogden, G.; von Kockritz-Blickwede, M. Extracellular Traps: An Ancient Weapon of Multiple Kingdoms. Biology 2020, 9, 34. [CrossRef] [PubMed]

37. Daniel, C.; Leppkes, M.; Muñoz, L.E.; Schley, G.; Schett, G.; Herrmann, M. Extracellular DNA traps in inflammation, injury and healing. Nat. Rev. Nephrol. 2019, 15, 559-575. [CrossRef] [PubMed]

38. Wartha, F.; Henriques-Normark, B. ETosis: A Novel Cell Death Pathway. Sci. Signal. 2008, 1, pe25. [CrossRef] [PubMed]

39. Clark, S.; Ma, A.C.; Tavener, S.A.; McDonald, B.; Goodarzi, Z.; Kelly, M.M.; Patel, K.D.; Chakrabarti, S.; McAvoy, E.; Sinclair, G.D.; et al. Platelet TLR4 activates neutrophil extracellular traps to ensnare bacteria in septic blood. Nat. Med. 2007, 13, 463-469. [CrossRef] [PubMed] 
40. Pilsczek, F.H.; Salina, D.; Poon, K.K.H.; Fahey, C.; Yipp, B.; Sibley, C.D.; Robbins, S.; Green, F.H.Y.; Surette, M.G.; Sugai, M.; et al. A Novel Mechanism of Rapid Nuclear Neutrophil Extracellular Trap Formation in Response to Staphylococcus aureus. J. Immunol. 2010, 185, 7413-7425. [CrossRef]

41. Byrd, A.S.; O’Brien, X.M.; Johnson, C.M.; Lavigne, L.M.; Reichner, J.S. An Extracellular Matrix-Based Mechanism of Rapid Neutrophil Extracellular Trap Formation in Response to Candida albicans. J. Immunol. 2013, 190, 4136-4148. [CrossRef] [PubMed]

42. Yipp, B.G.; Kubes, P. NETosis: How vital is it? Blood 2013, 122, 2784-2794. [CrossRef]

43. McIlroy, D.J.; Jarnicki, A.G.; Au, G.G.; Lott, N.; Smith, D.W.; Hansbro, P.; Balogh, Z.J. Mitochondrial DNA neutrophil extracellular traps are formed after trauma and subsequent surgery. J. Crit. Care 2014, 29, 1133.e1-1133.e5. [CrossRef]

44. Yousefi, S.; Mihalache, C.C.; Kozlowski, E.O.; Schmid, I.; Simon, H.U. Viable neutrophils release mitochondrial DNA to form neutrophil extracellular traps. Cell Death Differ. 2009, 16, 1438-1444. [CrossRef]

45. Seper, A.; Hosseinzadeh, A.; Gorkiewicz, G.; Lichtenegger, S.; Roier, S.; Leitner, D.R.; Röhm, M.; Grutsch, A.; Reidl, J.; Urban, C.F.; et al. Vibrio cholerae Evades Neutrophil Extracellular Traps by the Activity of Two Extracellular Nucleases. PLoS Pathog. 2013, 9, e1003614. [CrossRef] [PubMed]

46. Wartha, F.; Beiter, K.; Albiger, B.; Fernebro, J.; Zychlinsky, A.; Normark, S.; Henriques-Normark, B. Capsule and d-alanylated lipoteichoic acids protect Streptococcus pneumoniae against neutrophil extracellular traps. Cell. Microbiol. 2007, 9, 1162-1171. [CrossRef]

47. Von Köckritz-Blickwede, M.; Goldmann, O.; Thulin, P.; Heinemann, K.; Norrby-Teglund, A.; Rohde, M.; Medina, E. Phagocytosisindependent antimicrobial activity of mast cells by means of extracellular trap formation. Blood 2008, 111, 3070-3080. [CrossRef]

48. Beiter, K.; Wartha, F.; Albiger, B.; Normark, S.; Zychlinsky, A.; Henriques-Normark, B. An Endonuclease Allows Streptococcus pneumoniae to Escape from Neutrophil Extracellular Traps. Curr. Biol. 2006, 16, 401-407. [CrossRef]

49. Juneau, R.A.; Pang, B.; Weimer, K.E.D.; Armbruster, C.E.; Swords, W.E. Nontypeable Haemophilus influenzae Initiates Formation of Neutrophil Extracellular Traps. Infect. Immun. 2011, 79, 431-438. [CrossRef]

50. Munafo, D.B.; Johnson, J.L.; Brzezinska, A.A.; Ellis, B.A.; Wood, M.R.; Catz, S.D. DNase I Inhibits a Late Phase of Reactive Oxygen Species Production in Neutrophils. J. Innate Immun. 2009, 1, 527-542. [CrossRef] [PubMed]

51. Ramos-Kichik, V.; Mondragón-Flores, R.; Mondragón-Castelán, M.; Gonzalez-Pozos, S.; Muñiz-Hernandez, S.; Rojas-Espinosa, O.; Chacon-Salinas, R.; Estrada-Parra, S.; Estrada-García, I. Neutrophil extracellular traps are induced by Mycobacterium tuberculosis. Tuberculosis 2009, 89, 29-37. [CrossRef]

52. McCormick, A.; Heesemann, L.; Wagener, J.; Marcos, V.; Hartl, D.; Loeffler, J.; Heesemann, J.; Ebel, F. NETs formed by human neutrophils inhibit growth of the pathogenic mold Aspergillus fumigatus. Microbes Infect. 2010, 12, 928-936. [CrossRef] [PubMed]

53. Bianchi, M.; Niemiec, M.J.; Siler, U.; Urban, C.F.; Reichenbach, J. Restoration of anti-Aspergillus defense by neutrophil extracellular traps in human chronic granulomatous disease after gene therapy is calprotectin-dependent. J. Allergy Clin. Immunol. 2011, 127, 1243-1252.e7. [CrossRef]

54. Urban, C.F.; Reichard, U.; Brinkmann, V.; Zychlinsky, A. Neutrophil extracellular traps capture and kill Candida albicans yeast and hyphal forms. Cell. Microbiol. 2006, 8, 668-676. [CrossRef]

55. Delbosc, S.; Alsac, J.-M.; Journé, C.; Louedec, L.; Castier, Y.; Bonnaure-Mallet, M.; Ruimy, R.; Rossignol, P.; Bouchard, P.; Michel, J.-B.; et al. Porphyromonas gingivalis Participates in Pathogenesis of Human Abdominal Aortic Aneurysm by Neutrophil Activation. Proof of Concept in Rats. PLoS ONE 2011, 6, e18679. [CrossRef] [PubMed]

56. Brogden, G.; von Köckritz-Blickwede, M.; Adamek, M.; Reuner, F.; Jung-Schroers, V.; Naim, H.Y.; Steinhagen, D. $\beta$-Glucan protects neutrophil extracellular traps against degradation by Aeromonas hydrophila in carp (Cyprinus carpio). Fish Shellfish Immunol. 2012, 33, 1060-1064. [CrossRef]

57. Gondaira, S.; Higuchi, H.; Nishi, K.; Iwano, H.; Nagahata, H. Mycoplasma bovis escapes bovine neutrophil extracellular traps. Vet. Microbiol. 2017, 199, 68-73. [CrossRef]

58. Gondaira, S.; Higuchi, H.; Iwano, H.; Nishi, K.; Nebu, T.; Nakajima, K.; Nagahata, H. Innate immune response of bovine mammary epithelial cells to Mycoplasma bovis. J. Vet. Sci. 2018, 19, 79-87. [CrossRef]

59. Villagra-Blanco, R.; Silva, L.M.R.; Muñoz-Caro, T.; Yang, Z.; Li, J.; Gärtner, U.; Taubert, A.; Zhang, X.; Hermosilla, C. Bovine Polymorphonuclear Neutrophils Cast Neutrophil Extracellular Traps against the Abortive Parasite Neospora caninum. Front. Immunol. 2017, 8, 606. [CrossRef] [PubMed]

60. Alarcón, P.; Manosalva, C.; Conejeros, I.; Carretta, M.D.; Muñoz-Caro, T.; Silva, L.M.R.; Taubert, A.; Hermosilla, C.; Hidalgo, M.A.; Burgos, R.A. d(-) Lactic Acid-Induced Adhesion of Bovine Neutrophils onto Endothelial Cells Is Dependent on Neutrophils Extracellular Traps Formation and CD11b Expression. Front. Immunol. 2017, 8, 975. [CrossRef]

61. Pérez, D.; Muñoz-Caro, T.; Silva, L.; Muñoz, M.; Molina, J.; Taubert, A.; Hermosilla, C.; Ruiz, A. Eimeria ninakohlyakimovae casts NOX-independent NETosis and induces enhanced IL-12, TNF- $\alpha$, IL-6, CCL2 and iNOS gene transcription in caprine PMN. Exp. Parasitol. 2021, 220, 108034. [CrossRef]

62. Pérez, D.; Munoz, M.; Molina, J.; Muñoz-Caro, T.; Silva, L.; Taubert, A.; Hermosilla, C.; Ruiz, A. Eimeria ninakohlyakimovae induces NADPH oxidase-dependent monocyte extracellular trap formation and upregulates IL-12 and TNF- $\alpha$, IL-6 and CCL2 gene transcription. Vet. Parasitol. 2016, 227, 143-150. [CrossRef]

63. Silva, L.M.R.; Muñoz-Caro, T.; Burgos, R.A.; Hidalgo, M.A.; Taubert, A.; Hermosilla, C. Far beyond phagocytosis: Phagocytederived extracellular traps act efficiently against protozoan parasites in vitro and in vivo. Mediat. Inflamm. 2016, 2016, 5898074. [CrossRef] [PubMed] 
64. Muñoz-Caro, T.; Rubio, R.M.; Silva, L.M.; Magdowski, G.; Gartner, U.; McNeilly, T.N.; Taubert, A.; Hermosilla, C. Leucocytederived extracellular trap formation significantly contributes to Haemonchus contortus larval entrapment. Parasites Vectors 2015, 8, 607. [CrossRef] [PubMed]

65. Muñoz-Caro, T.; Lendner, M.; Daugschies, A.; Hermosilla, C.; Taubert, A. NADPH oxidase, MPO, NE, ERK1/2, p38 MAPK and $\mathrm{Ca}^{2+}$ influx are essential for Cryptosporidium parvum-induced NET formation. Dev. Comp. Immunol. 2015, 52, 245-254. [CrossRef]

66. Muñoz-Caro, T.; Da Silva, L.M.R.; Rentería-Solis, Z.; Taubert, A.; Hermosilla, C. Neutrophil extracellular traps in the intestinal mucosa of Eimeria-infected animals. Asian Pac. J. Trop. Biomed. 2016, 6, 301-307. [CrossRef]

67. Muñoz-Caro, T.; Gibson, A.; Conejeros, I.; Werling, D.; Taubert, A.; Hermosilla, C. The Role of TLR2 and TLR4 in Recognition and Uptake of the Apicomplexan Parasite Eimeria bovis and Their Effects on NET Formation. Pathogens 2021, 10, 118. [CrossRef]

68. Yildiz, K.; Gokpinar, S.; Gazyagci, A.N.; Babur, C.; Sursal, N.; Azkur, A.K. Role of NETs in the difference in host susceptibility to Toxoplasma gondii between sheep and cattle. Vet. Immunol. Immunopathol. 2017, 189, 1-10. [CrossRef] [PubMed]

69. Jerjomiceva, N.; Seri, H.; Völlger, L.; Wang, Y.; Zeitouni, N.; Naim, H.Y.; Von Köckritz-Blickwede, M. Enrofloxacin Enhances the Formation of Neutrophil Extracellular Traps in Bovine Granulocytes. J. Innate Immun. 2014, 6, 706-712. [CrossRef]

70. Revelo, X.; Waldron, M. In vitro effects of Escherichia coli lipopolysaccharide on the function and gene expression of neutrophils isolated from the blood of dairy cows. J. Dairy Sci. 2012, 95, 2422-2441. [CrossRef] [PubMed]

71. Vezina, B.; Al-Harbi, H.; Ramay, H.R.; Soust, M.; Moore, R.J.; Olchowy, T.W.J.; Alawneh, J.I. Sequence characterisation and novel insights into bovine mastitis-associated Streptococcus uberis in dairy herds. Sci. Rep. 2021, 11, 3046. [CrossRef] [PubMed]

72. Pisanu, S.; Cubeddu, T.; Pagnozzi, D.; Rocca, S.; Cacciotto, C.; Alberti, A.; Marogna, G.; Uzzau, S.; Addis, M.F. Neutrophil extracellular traps in sheep mastitis. Vet. Res. 2015, 46, 59. [CrossRef]

73. Khandpur, R.; Carmona-Rivera, C.; Vivekanandan-Giri, A.; Gizinski, A.; Yalavarthi, S.; Knight, J.S.; Friday, S.; Li, S.; Patel, R.M.; Subramanian, V.; et al. NETs Are a Source of Citrullinated Autoantigens and Stimulate Inflammatory Responses in Rheumatoid Arthritis. Sci. Transl. Med. 2013, 5, 178ra40. [CrossRef]

74. Jennette, J.C.; Falk, R.J. Small-Vessel Vasculitis. N. Engl. J. Med. 1997, 337, 1512-1523. [CrossRef]

75. Söderberg, D.; Kurz, T.; Motamedi, A.; Hellmark, T.; Eriksson, P.; Segelmark, M. Increased levels of neutrophil extracellular trap remnants in the circulation of patients with small vessel vasculitis, but an inverse correlation to anti-neutrophil cytoplasmic antibodies during remission. Rheumatology 2015, 54, 2085-2094. [CrossRef] [PubMed]

76. Hanses, F.; Park, S.; Rich, J.; Lee, J.C. Reduced Neutrophil Apoptosis in Diabetic Mice during Staphylococcal Infection Leads to Prolonged Tnf $\alpha$ Production and Reduced Neutrophil Clearance. PLoS ONE 2011, 6, e23633. [CrossRef]

77. Wong, S.L.; Demers, M.; Martinod, K.; Gallant, M.; Wang, Y.; Goldfine, A.B.; Kahn, C.R.; Wagner, D.D. Diabetes primes neutrophils to undergo NETosis, which impairs wound healing. Nat. Med. 2015, 21, 815-819. [CrossRef]

78. Berger-Achituv, S.; Brinkmann, V.; Abu-Abed, U.; Kühn, L.I.; Ben-Ezra, J.; Elhasid, R.; Zychlinsky, A. A proposed role for neutrophil extracellular traps in cancer immunoediting. Front. Immunol. 2013, 4, 48. [CrossRef] [PubMed]

79. Delgado-Rizo, V.; Martinez-Guzman, M.; Iñiguez-Gutierrez, L.; García-Orozco, A.; Alvarado-Navarro, A.; Fafutis-Morris, M. Neutrophil Extracellular Traps and Its Implications in Inflammation: An Overview. Front. Immunol. 2017, 8, 81. [CrossRef] [PubMed]

80. Fuchs, T.A.; Brill, A.; Duerschmied, D.; Schatzberg, D.; Monestier, M.; Myers, D.D.; Wrobleski, S.K.; Wakefield, T.W.; Hartwig, J.H.; Wagner, D.D. Extracellular DNA traps promote thrombosis. Proc. Natl. Acad. Sci. USA 2010, 107, 15880-15885. [CrossRef]

81. Xu, J.; Zhang, X.; Pelayo, R.; Monestier, M.; Ammollo, C.T.; Semeraro, F.; Taylor, F.B.; Esmon, N.L.; Lupu, F.; Esmon, C.T. Extracellular histones are major mediators of death in sepsis. Nat. Med. 2009, 15, 1318-1321. [CrossRef]

82. Engelmann, B.; Massberg, S. Thrombosis as an intravascular effector of innate immunity. Nat. Rev. Immunol. 2012, 13, 34-45. [CrossRef] [PubMed]

83. Fernández, M.H.; Vrba, E.S. A complete estimate of the phylogenetic relationships in Ruminantia: A dated species-level supertree of the extant ruminants. Biol. Rev. 2005, 80, 269-302. [CrossRef]

84. Simianer, H.; Reimer, C. COVID-19: A "black swan" and what animal breeding can learn from it. Anim. Front. 2021, 11, 57-59. [CrossRef]

85. Leung, T.L.F.; Bates, A.E. More rapid and severe disease outbreaks for aquaculture at the tropics: Implications for food security. J. Appl. Ecol. 2012, 50, 215-222. [CrossRef]

86. Roeber, F.; Jex, A.R.; Gasser, R.B. Impact of gastrointestinal parasitic nematodes of sheep, and the role of advanced molecular tools for exploring epidemiology and drug resistance-An Australian perspective. Parasites Vectors 2013, 6, 153. [CrossRef] [PubMed]

87. Worku, M.; Franco, R.; Baldwin, K. Efficacy of garlic as an anthelmintic in adult Boer goats. Arch. Biol. Sci. 2009, 61, 135-140. [CrossRef]

88. Gasbarre, L.C.; Leighton, E.A.; Sonstegard, T. Role of the bovine immune system and genome in resistance to gastrointestinal nematodes. Vet. Parasitol. 2001, 98, 51-64. [CrossRef]

89. Paape, M.; Rautiainen, P.; Lilius, E.; Malstrom, C.; Elsasser, T. Development of Anti-Bovine TNF- $\alpha$ mAb and ELISA for Quantitating TNF- $\alpha$ in Milk after Intramammary Injection of Endotoxin. J. Dairy Sci. 2002, 85, 765-773. [CrossRef]

90. Fingerhut, L.; Dolz, G.; De Buhr, N. What Is the Evolutionary Fingerprint in Neutrophil Granulocytes? Int. J. Mol. Sci. 2020, 21, 4523. [CrossRef]

91. Asiamah, E.K.; Adjei-Fremah, S.; Ekwemalor, K.; Sordillo, L.; Worku, M. Parity and Periparturient Period Affects Galectin Gene Expression in Holstein Cow Blood. J. Appl. Biotechnol. 2018, 6, 19. [CrossRef] 
92. Asiamah, E.K.; Adjei-Fremah, S.; Osei, B.; Ekwemalor, K.; Worku, M. An Extract of Sericea Lespedeza Modulates Production of Inflammatory Markers in Pathogen Associated Molecular Pattern (PAMP) Activated Ruminant Blood. J. Agric. Sci. $2016,8,1$. [CrossRef]

93. Asiamah, E.K.; Ekwemalor, K.; Adjei-Fremah, S.; Osei, B.; Newman, R.; Worku, M. Natural and synthetic pathogen associated molecular patterns modulate galectin expression in cow blood. J. Anim. Sci. Technol. 2019, 61, 245-253. [CrossRef]

94. Osei, B.; Worku, M.; Adjei-Fremah, S.; Asiamah, E.; Ekwemalor, K.; Eluka-Okoludoh, E.; Mulakala, B. Galectin Secretion and Modulation in Sheep Blood. J. Mol. Biol. Res. 2018, 8, p183. [CrossRef]

95. Ekwemalor, K.; Asiamah, E.; Adjei-Fremah, S.; Worku, M. Effect of a Mushroom (Coriolus versicolor) Based Probiotic on Goat Health. Am. J. Anim. Vet. Sci. 2016, 11, 108-118. [CrossRef]

96. Ekwemalor, K.; Asiamah, E.K.; Osei, B.; Ismail, H.; Worku, M. Evaluation of the Effect of Probiotic Administration on Gene Expression in Goat Blood. J. Mol. Biol. Res. 2017, 7, 88. [CrossRef]

97. Ekwemalor, K.; Adjei-Fremah, S.; Asiamah, E.; Eluka-Okoludoh, E.; Osei, B.; Worku, M. Systemic expression of galectin genes in periparturient goats. Small Rumin. Res. 2018, 168, 60-68. [CrossRef]

98. Sarah, A.-F.; Jackai, L.E.; Worku, M. Analysis of Phenolic Content and Antioxidant Properties of Selected Cowpea Varieties Tested in Bovine Peripheral Blood. Am. J. Anim. Vet. Sci. 2015, 10, 235-245.

99. Erpenbeck, L.; Gruhn, A.L.; Kudryasheva, G.; Günay, G.; Meyer, D.; Busse, J.; Neubert, E.; Schön, M.P.; Rehfeldt, F.; Kruss, S. Effect of adhesion and substrate elasticity on neutrophil extracellular trap formation. Front. Immunol. 2019, 10, 2320. [CrossRef] [PubMed]

100. Sabbione, F.; Keitelman, I.A.; Iula, L.; Ferrero, M.; Giordano, M.N.; Baldi, P.; Rumbo, M.; Jancic, C.; Trevani, A.S. Neutrophil Extracellular Traps Stimulate Proinflammatory Responses in Human Airway Epithelial Cells. J. Innate Immun. 2017, 9, 387-402. [CrossRef]

101. Wei, Z.; Wang, J.; Wang, Y.; Wang, C.; Liu, X.; Han, Z.; Fu, Y.; Yang, Z. Effects of Neutrophil Extracellular Traps on Bovine Mammary Epithelial Cells in vitro. Front. Immunol. 2019, 10, 1003. [CrossRef]

102. Fichtner, T.; Kotarski, F.; Gärtner, U.; Conejeros, I.; Hermosilla, C.; Wrenzycki, C.; Taubert, A. Bovine sperm samples induce different NET phenotypes in a NADPH oxidase-, PAD4-, and Ca++-dependent process. Biol. Reprod. 2020, 102, 902-914. [CrossRef] [PubMed]

103. Zambrano, F.; Silva, L.; Uribe, P.; Gärtner, U.; Taubert, A.; Schulz, M.; Sánchez, R.; Hermosilla, C. SOCE-inhibitor reduced human sperm-induced formation of neutrophil extracellular traps. Reproduction 2021, 161, 21-29. [CrossRef]

104. Bean, A.G.D.; Baker, M.L.; Stewart, C.R.; Deffrasnes, C.; Wang, L.-F.; Lowenthal, J.W. Studying immunity to zoonotic diseases in the natural host - keeping it real. Nat. Rev. Immunol. 2013, 13, 851-861. [CrossRef] [PubMed]

105. Abdel-Moneim, A.M.E.; Shehata, A.M.; Alzahrani, S.O.; Shafi, M.E.; Mesalam, N.M.; Taha, A.E.; Swelum, A.A.; Arif, M.; Fayyaz, M.; Abd El-Hack, M.E. The role of polyphenols in poultry nutrition. J. Anim. Physiol. Anim. Nutr. 2020, 104, 1851-1866. [CrossRef]

106. Mutua, V.; Gershwin, L.J. A Review of Neutrophil Extracellular Traps (NETs) in Disease: Potential Anti-NETs Therapeutics. Clin. Rev. Allergy Immunol. 2020, 1-18. [CrossRef]

107. Zappulli, V.; Ferro, S.; Bonsembiante, F.; Brocca, G.; Calore, A.; Cavicchioli, L.; Centelleghe, C.; Corazzola, G.; De Vreese, S.; Gelain, M.E.; et al. Pathology of Coronavirus Infections: A Review of Lesions in Animals in the One-Health Perspective. Animals 2020, 10, 2377. [CrossRef]

108. Ekwemalor, K.; Adjei-Fremah, S.; Asiamah, E.; Worku, M. Molecular Genetics and Genome Biology of Goats. In Goat Science; IntechOpen Limited: London, UK, 2018.

109. Paape, M.J.; Bannerman, D.D.; Zhao, X.; Lee, J.-W. The bovine neutrophil: Structure and function in blood and milk. Vet. Res. 2003, 34, 597-627. [CrossRef]

110. Vong, L.; Lorentz, R.J.; Assa, A.; Glogauer, M.; Sherman, P. Probiotic Lactobacillus rhamnosus Inhibits the Formation of Neutrophil Extracellular Traps. J. Immunol. 2014, 192, 1870-1877. [CrossRef] [PubMed]

111. Cacciotto, C.; Cubeddu, T.; Addis, M.F.; Anfossi, A.G.; Tedde, V.; Tore, G.; Carta, T.; Rocca, S.; Chessa, B.; Pittau, M.; et al. Mycoplasma lipoproteins are major determinants of neutrophil extracellular trap formation. Cell. Microbiol. 2016, 18, 1751-1762. [CrossRef]

112. Aulik, N.A.; Hellenbrand, K.M.; Czuprynski, C.J. Mannheimia haemolytica and Its Leukotoxin Cause Macrophage Extracellular Trap Formation by Bovine Macrophages. Infect. Immun. 2012, 80, 1923-1933. [CrossRef]

113. Aulik, N.A.; Hellenbrand, K.M.; Klos, H.; Czuprynski, C.J. Mannheimia haemolytica and Its Leukotoxin Cause Neutrophil Extracellular Trap Formation by Bovine Neutrophils. Infect. Immun. 2010, 78, 4454-4466. [CrossRef]

114. Hellenbrand, K.M.; Forsythe, K.M.; Rivera-Rivas, J.J.; Czuprynski, C.J.; Aulik, N.A. Histophilus somni causes extracellular trap formation by bovine neutrophils and macrophages. Microb. Pathog. 2013, 54, 67-75. [CrossRef]

115. Maksimov, P.; Hermosilla, C.; Kleinertz, S.; Hirzmann, J.; Taubert, A. Besnoitia besnoiti infections activate primary bovine endothelial cells and promote PMN adhesion and NET formation under physiological flow condition. Parasitol. Res. 2016, 115, 1991-2001. [CrossRef] [PubMed]

116. Grob, D.; Conejeros, I.; Velásquez, Z.D.; Preußer, C.; Gärtner, U.; Alarcón, P.; Burgos, R.A.; Hermosilla, C.; Taubert, A. Trypanosoma brucei brucei Induces Polymorphonuclear Neutrophil Activation and Neutrophil Extracellular Traps Release. Front. Immunol. 2020, 11, 559561. [CrossRef] [PubMed] 
117. Villagra-Blanco, R.; Silva, L.; Gärtner, U.; Wagner, H.; Failing, K.; Wehrend, A.; Taubert, A.; Hermosilla, C. Molecular analyses on Neospora caninum-triggered NETosis in the caprine system. Dev. Comp. Immunol. 2017, 72, 119-127. [CrossRef]

118. Yang, Z.; Wei, Z.; Hermosilla, C.; Taubert, A.; He, X.; Wang, X.; Gong, P.; Li, J.; Zhang, X. Caprine Monocytes Release Extracellular Traps against Neospora caninum In Vitro. Front. Immunol. 2018, 8, 2016. [CrossRef] [PubMed]

119. Wang, Y.; Li, M.; Stadler, S.C.; Correll, S.; Li, P.; Wang, D.; Hayama, R.; Leonelli, L.; Han, H.; Grigoryev, S.A.; et al. Histone hypercitrullination mediates chromatin decondensation and neutrophil extracellular trap formation. J. Cell Biol. 2009, 184, 205-213. [CrossRef] [PubMed]

120. Zhou, E.; Wu, Z.; Zhu, X.; Li, P.; Wang, J.; Yang, Z. Characterization of Bovine Neutrophil Extracellular Traps Induced by Histamine. Res. Sq. 2021. [CrossRef]

121. Hahn, S.; Giaglis, S.; Chowdury, C.S.; Hösli, I.; Hasler, P. Modulation of neutrophil NETosis: Interplay between infectious agents and underlying host physiology. Semin. Immunopathol. 2013, 35, 439-453. [CrossRef]

122. Peixoto, R.; Silva, L.M.R.; López-Osório, S.; Zhou, E.; Gärtner, U.; Conejeros, I.; Taubert, A.; Hermosilla, C. Fasciola hepatica induces weak NETosis and low production of intra- and extracellular ROS in exposed bovine polymorphonuclear neutrophils Dev. Comp. Immunol. 2021, 114, 103787. [CrossRef] [PubMed]

123. Alarcón, P.; Manosalva, C.; Quiroga, J.; Belmar, I.; Álvarez, K.; Díaz, G.; Taubert, A.; Hermosilla, C.; Carretta, M.D.; Burgos, R.A.; et al. Oleic and Linoleic Acids Induce the Release of Neutrophil Extracellular Traps via Pannexin 1-Dependent ATP Release and P2X1 Receptor Activation. Front. Vet. Sci. 2020, 7. [CrossRef]

124. Hakkim, A.; Fuchs, T.A.; Martinez, N.E.; Hess, S.; Prinz, H.; Zychlinsky, A.; Waldmann, H. Activation of the Raf-MEK-ERK pathway is required for neutrophil extracellular trap formation. Nat. Chem. Biol. 2010, 7, 75-77. [CrossRef]

125. Bannerman, D.D.; Paape, M.J.; Lee, J.-W.; Zhao, X.; Hope, J.C.; Rainard, P. Escherichia coli and Staphylococcus aureus Elicit Differential Innate Immune Responses following Intramammary Infection. Clin. Vaccine Immunol. 2004, 11, 463-472. [CrossRef] [PubMed]

126. Worku, M.; Morris, A. Binding of different forms of lipopolysaccharide and gene expression in bovine blood neutrophils. J. Dairy Sci. 2009, 92, 3185-3193. [CrossRef] [PubMed]

127. Elsherif, L.; Sciaky, N.; Metts, C.A.; Modasshir, M.; Rekleitis, I.; Burris, C.A.; Walker, J.A.; Ramadan, N.; Leisner, T.M.; Holly, S.P.; et al. Machine Learning to Quantitate Neutrophil NETosis. Sci. Rep. 2019, 9, 16891. [CrossRef]

128. Adjei-Fremah, S.; Everett, A.; Franco, R.; Moultone, K.; Asiamah, E.; Ekwemalor, K.; Jackai, L.E.; Whitley, N.; Schimmel, K.; Worku, M. Health and production benefits of feeding cowpeas to goats. J. Anim. Sci. 2016, 94, 80-81. [CrossRef]

129. Fisher, J.; Mohanty, T.; Karlsson, C.; Khademi, S.M.H.; Malmström, E.; Frigyesi, A.; Nordenfelt, P.; Malmstrom, J.; Linder, A Proteome profiling of recombinant DNase therapy in reducing NETs and aiding recovery in COVID-19 patients. Mol. Cell. Proteom. MCP 2021, 100113. [CrossRef]

130. Adjei-Fremah, S.; Asiamah, E.K.; Ekwemalor, K.; Jackai, L.; Schimmel, K.; Worku, M. Modulation of Bovine Wnt Signaling Pathway Genes by Cowpea Phenolic Extract. J. Agric. Sci. 2016, 8, 21. [CrossRef]

131. Worku, M.; Franco, R.; Miller, J. Evaluation of the Activity of Plant Extracts in Boer Goats. Am. J. Anim. Vet. Sci. 2009, 4, 72-79. [CrossRef]

132. Worku, M.; Abdalla, A.; Adjei-Fremah, S.; Ismail, H. The Impact of Diet on Expression of Genes Involved in Innate Immunity in Goat Blood. J. Agric. Sci. 2016, 8, 1. [CrossRef]

133. Adjei-Fremah, S.; Ekwemalor, K.; Asiamah, E.; Ismail, H.; Worku, M. Transcriptional profiling of the effect of lipopolysaccharide (LPS) pretreatment in blood from probiotics-treated dairy cows. Genom. Data 2016, 10, 15-18. [CrossRef] [PubMed]

134. Adjei-Fremah, S.; Ekwemalor, K.; Worku, M.; Ibrahim, S. Probiotics and Ruminant Health; IntechOpen Limited: London, UK, 2018.

135. Vorobjeva, N.V.; Pinegin, B.V. Effects of the antioxidants Trolox, Tiron and Tempol on neutrophil extracellular trap formation. Immunobiology 2016, 221, 208-219. [CrossRef]

136. Kirchner, T.; Hermann, E.; Möller, S.; Klinger, M.; Solbach, M.D.W.; Laskay, T.; Behnen, M. Flavonoids and 5-Aminosalicylic Acid Inhibit the Formation of Neutrophil Extracellular Traps. Mediat. Inflamm. 2013, 2013, 710239. [CrossRef]

137. Adjei-Fremah, S.; Worku, M. Cowpea polyphenol extract regulates galectin gene expression in bovine blood. Anim. Biotechnol. 2021, 32, 1-12. [CrossRef] [PubMed]

138. Adjei-Fremah, S.; Jackai, L.E.N.; Schimmel, K.; Worku, M. Microarray analysis of the effect of Cowpea (Vigna unguiculata) phenolic extract in bovine peripheral blood. J. Appl. Anim. Res. 2016, 46, 100-106. [CrossRef]

139. Adjei-Fremah, S.; Jackai, L.E.; Schimmel, K.; Worku, M. Immunomodulatory activities of polyphenol extract from cowpea (Vigna unguiculata) on bovine polymorphonuclear neutrophils. J. Anim. Sci. 2016, 94, 86-87. [CrossRef]

140. Adjei-Fremah, S.; Asiamah, E.; Ekwemalor, K.; Osei, B.; Ismail, H.; Jackai, L.E.; Worku, M. The anti-inflammatory effect of cowpea polyphenol in bovine blood. J. Anim. Sci. 2017, 95, 27. [CrossRef]

141. Worku, M.; Adjei-Fremah, S.; Whitley, N.; Jackai, L. Effect of Cowpea (Vigna unguiculata) Pasture Grazing on Growth, Gastrointestinal Parasite Infection and Immune Response Biomarkers of Goat. J. Agric. Sci. 2017, 10, 27. [CrossRef]

142. Ekwemalor, K.; Asiamah, E.; Worku, M. Effect of a Mushroom (Coriolus versicolor) Based Probiotic on the Expression of Toll-like Receptors and Signal Transduction in Goat Neutrophils. J. Mol. Biol. Res. 2015, 6, 71. [CrossRef]

143. Gyenai, K.; Worku, M.; Tajkarimi, M.; Ibrahim, S. Influence of Probiotics on Coccidia, H. Contortus and Markers of Infection in Goats. Am. J. Anim. Vet. Sci. 2016, 11, 91-99. [CrossRef] 
144. Salvesen, Ø.; Reiten, M.R.; Heegaard, P.M.H.; Tranulis, M.A.; Espenes, A.; Skovgaard, K.; Ersdal, C. Activation of innate immune genes in caprine blood leukocytes after systemic endotoxin challenge. BMC Vet. Res. 2016, 12, 241. [CrossRef]

145. Asiamah, E.K. Galectin Gene Expression and Secretion in Dairy Cow Blood; North Carolina Agricultural and Technical State University: Greensboro, NC, USA, 2018.

146. Meglia, G.E.; Johannisson, A.; Petersson, L.; Waller, K.P. Investigation in blood Leukocytes and Neutrophils in Periparturient Dairy Cow. Sci. J. Anim. Vet. Sci. 2018, 1, 001-009.

147. Li, C.; Batistel, F.; Osorio, J.S.; Drackley, J.K.; Luchini, D.; Loor, J.J. Peripartal rumen-protected methionine supplementation to higher energy diets elicits positive effects on blood neutrophil gene networks, performance and liver lipid content in dairy cows. J. Anim. Sci. Biotechnol. 2016, 7, 18. [CrossRef]

148. Riboni, M.V.; Zhou, Z.; Jacometo, C.; Minuti, A.; Trevisi, E.; Luchini, D.; Loor, J. Supplementation with rumen-protected methionine or choline during the transition period influences whole-blood immune response in periparturient dairy cows. $J$. Dairy Sci. 2017, 100, 3958-3968. [CrossRef] [PubMed]

149. Osorio, J.S.; Ji, P.; Drackley, J.K.; Luchini, D.; Loor, J.J. Supplemental Smartamine M or MetaSmart during the transition period benefits postpartal cow performance and blood neutrophil function. J. Dairy Sci. 2013, 96, 6248-6263. [CrossRef] [PubMed]

150. Stella, S.; Velasco-Acosta, D.; Skenandore, C.; Zhou, Z.; Steelman, A.; Luchini, D.; Cardoso, F. Improved uterine immune mediators in Holstein cows supplemented with rumen-protected methionine and discovery of neutrophil extracellular traps (NET). Theriogenology 2018, 114, 116-125. [CrossRef]

151. Parker, H.; Albrett, A.M.; Kettle, A.J.; Winterbourn, C.C. Myeloperoxidase associated with neutrophil extracellular traps is active and mediates bacterial killing in the presence of hydrogen peroxide. J. Leukoc. Biol. 2011, 91, 369-376. [CrossRef]

152. Petretto, A.; Bruschi, M.; Pratesi, F.; Croia, C.; Candiano, G.; Ghiggeri, G.M.; Migliorini, P. Neutrophil extracellular traps (NET) induced by different stimuli: A comparative proteomic analysis. PLoS ONE 2019, 14, e218946. [CrossRef]

153. Asiamah, E.K.; Vailati-Riboni, M.; Zhou, Z.; Xu, T.; Loor, J.; Schimmel, K.; Worku, M. Rumen-protected methionine supplementation during the peripartal period alters the expression of galectin genes associated with inflammation in peripheral neutrophils and secretion in plasma of Holstein cows. J. Dairy Res. 2019, 86, 394-398. [CrossRef]

154. Cooper, D.; Iqbal, A.J.; Gittens, B.R.; Cervone, C.; Perretti, M. The effect of galectins on leukocyte trafficking in inflammation: Sweet or sour? Ann. N. Y. Acad. Sci. 2012, 1253, 181-192. [CrossRef]

155. Schorn, C.; Janko, C.; Krenn, V.; Zhao, Y.; Munoz, L.E.; Schett, G.; Herrmann, M. Bonding the foe-NETting neutrophils immobilize the pro-inflammatory monosodium urate crystals. Front. Immunol. 2012, 3, 376. [CrossRef] [PubMed]

156. Nishi, N.; Shoji, H.; Seki, M.; Itoh, A.; Miyanaka, H.; Yuube, K.; Hirashima, M.; Nakamura, T. Galectin-8 modulates neutrophil function via interaction with integrin $\alpha$ M. Glycobiology 2003, 13, 755-763. [CrossRef]

157. Thurston, T.; Wandel, M.P.; Von Muhlinen, N.; Foeglein, Á.; Randow, F. Galectin 8 targets damaged vesicles for autophagy to defend cells against bacterial invasion. Nat. Cell Biol. 2012, 482, 414-418. [CrossRef] [PubMed]

158. Díaz-Godínez, C.; Carrero, J.C. The state of art of neutrophil extracellular traps in protozoan and helminthic infections. Biosci. Rep. 2019, 39. [CrossRef] [PubMed] 